\title{
Human Resource Management and Business Adaptability and Adjustability in Business Development
}

\author{
Fanny Y F Young (Corresponding author) \\ Dept. of Business Administration, Hong Kong Shue Yan University \\ Wai Tsui Crescent, North Point, Hong Kong \\ Tel: 852-2570-7110Ｅ-mail: drfyoung@gmail.com
}

Received: July 23, 2017 Accepted: August 16, 2017 Published: August 17, 2017

doi:10.5296/jad.v3i2.11587 URL: https://doi.org/10.5296/jad.v3i2.11587

\begin{abstract}
Business adaptability and adjustability is highly important for the business development. It was suggested human resource managers and executives could pay an important contribution to this area. The aim of this study was to search the literature to see how the human resource managers and executives can improve the business adaptability and change of the companies. The internet was searched using various search engines like Google Scholars, Proquest and Google using keywords like human resource management, business adaptability and adjustability and business resilience. All selected papers were individually studied and any relevant materials were identified. Result showed that there were roles of human resource managers and executives in building business adaptability and adjustability such as acting as strategic partners, employee sponsors or advocates, change mentors and there were contributions which include transition the human resource department to a profitability factor; making profit to the company and engaging in people-focused approach to business continuity planning for crisis.
\end{abstract}

Keywords: Human resource management, Business Adaptability and Adjustability 


\section{Introduction}

The ability to adjust easily to change in a company is very important for the business development. Why need change? The companies need to increase the ability of systems and processes to effectively support a business under any adverse, fast changing, or unexpected condition. In other words, the companies have to quickly adapt to disruptions while maintaining continuous business operations and safeguarding people, assets and overall brand equity (Rouse, 2014).

Most of the companies generally understand that only the top management should be involved in the business adaptability and adjustability. They are rarely willing to invite human resource managers and executives to engage in the business adaptability and adjustability as they reckon that human resource managers and executives are just responsible for human resource planning, recruiting, selection, training and compensation. Nevertheless, they are equipped to face and deal with the dynamic changes of the business environment. Hence, it is better for companies to invite them to engage in business adaptability and adjustability rather than just require them to carry out their daily routine practices (Rouse, 2014).

In this study the literature was searched on how the human resource managers and executives can improve the business adaptability and change of the companies.

\section{Methodology}

The internet was searched using various search engines like Google Scholars, Proquest and Google using keywords like human resource management, business adaptability and adjustability and business resilience. All selected papers were individually studied and any relevant materials were identified. The findings from the papers were as follows.

\section{Roles of Human Resource Managers and Executives in Building Business Adaptability and Adjustability}

Today's companies cannot afford to have human resource departments that cannot contribute to lead modern thinking and to increase company profitability. In order to improve business adaptability and adjustability in the challenging economic environment, human resource managers and executives, can be considered to be strategic partners, employee sponsors or advocates and change mentors (Ulrich, 1997).

\subsection{Human Resource Managers and Executives Act as Strategic Partners}

As strategic partners, the human resource managers and executives aim at supporting the overall organization-wide strategic business plans and objectives. They should be knowledgeable about the working process in different departments. This strategic partnership utilised human resource services such as the design of working conditions, hiring and strategic compensation. They need to think like the businessperson and cooperate with finance and accounting departments. They can be responsible for cost reductions, evaluation and measurement of the effectiveness of all human resource programs and processes (Heathfield, 2016). To illustrate, the Hong Kong and Shanghai Banking Corporation initially 
tried to dismiss 3000 employees within 3 years from 2011 to 2012 . However, with the suggestion from the human resource department that this action would negatively affect the employees' performance and morale, the senior management personnel accepted the suggestion and finally canceled the related action (eElderly, 2012). A successful and functional strategic partnership is important to prevent a business recession occurs in companies, human resource managers and executives can establish cross-training program to coordinate different departments to be the strategic partners (Heathfield, 2016).

To illustrate, human resource managers and executives can cross-train employees on key skills and capabilities so that they can take on new responsibilities (IBM Global Services, 2009). Cross-training aims at training employees in a wide range of skills, so employees are knowledgeable about the roles and responsibilities of each position of the team. When the business recession occurred, cross-trained employees could fill in any positions of the team. Cross-training is useful for the human resource managers and executives to create strategic partnership with other departments and plan for the emergency measure for the occurrence of business adaptability and adjustability (Heathfield, 2016). To further illustrate, by cross-trained the employees among all departments, Birchcrest Tree \& Landscape's human resource managers and executives ran a lean and efficient human resource planning. Employees were able to move into other departments when there was a need in another business area. For example, those employees who installed hardscapes or did planting work were cross-trained to do tree work during winter or times when there's less landscape work. As a result, Dave Dailey, the owner of Birchcrest Tree \& Landscape, commented that "While other landscape companies pay the maximum unemployment rate, ours runs low to average." (Payton, 2015). This is a successful case that Birchcrest's human resource managers and executives solved the problem of the high unemployment rate in the landscape industry. The Birchcrest's human resource managers and executives not only eliminated the need for seasonal workers but also saved money to maximize the company's profitability. Hence, the strategic partner role of human resource managers and executives can contribute to build business adaptability and adjustability in challenging economic environment.

\subsection{Human Resource Managers and Executives Act as Employee Sponsors or Advocates}

In order to be an effective employee sponsor or advocate, human resource managers and executives can utilize their knowledge and expertise to support their employees. Human resource managers can use the different methods during challenging economic environment in order to reduce the impact suffered and sustain the business and create a positive environment. In doing so, employees will become less stressful and motivated, and will in turn increase their productivity (Heathfield, 2016).

One of the methods to achieve the above is to adopt the flexible work arrangement. This arrangement is an employee assistance program, which consists flexible working hours and home-base work, can be the first step human resource managers and executives can do. Instead of imposing standardized office hour, companies may adopt flexible time, like from $10 \mathrm{am}$ to $4 \mathrm{pm}$. Adopting the shorten office hours actually benefits work productivity since employees are entrusted with higher autonomy. It will also build up a stronger sense of 
belongings to the organization as the employees may think the company concerns about their needs and benefit. Hence, they are willing to engage with the organization towards its business goal (Hong Kong Labour Department, 2015). Home-base work or work-at-home provides employees to work time-effectively and attracts diversified workforces, such as women, foreigners, or even the disable, to work. Hence, flexible work arrangement can reduce the chance of employees transmitting the disease at the office, which provides sense of health-caring under the uncertainty (Heathfield, 2016).

In addition, the human resource managers and executives can set a goal for the employees, communicate with and empower them. Besides, they can build up employee ownership by establishing the organizational culture. As a result, employees will have the related competency and commitment to serve the customers with higher quality (Heathfield, 2016).

\subsection{Human Resource Managers and Executives Act as Change Mentors}

To be good change mentors, human resource managers and executives should be knowledgeable and able to implement the most suitable strategies in the challenging economic environment. In order to minimize employee dissatisfaction and the attitude of resistance to change, they should link the change to the strategic needs of the organization. For example, in the financial crisis in 2008, many top managements preferred to reduce employees' bonus and benefits in order to relieve the economic burden for company. This would induce employees' dissatisfaction. Companies could announce to all employees that their companies were facing hard time due to the challenging external environment. The cost saving from employees' contribution could effectively help companies get rid of the difficulties and companies promised to add double benefits to employees when the companies returned to normal route in the nearby future. Human resource managers and executives should always consciously help the companies create the right organization cultures, measure employee's satisfaction levels and achieve the company's goals. These strategies can relieve the burden of companies in challenging condition. It is also especially important that company should build a concrete foundation and implement before the crisis or disaster arrived, otherwise company will be suffered a lot without any planning, this will be discussed in more detail at the end of this paper (Heathfield, 2016).

Besides, human resource managers and executives can constantly evaluate the effectiveness of their department functions, this is to know whether they match the role of sponsors with different departments and work practices or not. A clear role of a department and well-defined division of labour can be very important parts of business adaptability and adjustability as they can deal with the different challenges met by company. Different departments have their own and unique functions, for example, human resource department is responsible for providing training to employees with skills needed for overcoming business adaptability and adjustability while marketing department is responsible for maintaining a positive image of company during challenging environment (Heathfield, 2016).

Promoting the overall success of the organization after evaluation is also important, especially in the hard time for the company. Human resource department should first identify the organizational mission, vision, values, goals and action plans, in order to further 
determine the measures which will tell the organization how well it is succeeding in all of this (Heathfield, 2016). Showing the success result to employees and general public can motivate employees and attract more stockholders to invest in the company.

To illustrate how the human resource managers and executives can act as the change mentor in the company, the Lewin's Change Theory Three Steps Model (Morrison, 2014) is used to illustrate the process of changing the attitude of employees in building business adaptability and adjustability.

Lewin's Change Theory is based on a 3-step process (Unfreeze-Change-Freeze) that provides a high-level approach to change. It gives human resource managers and executives a framework to implement a change effort. As change can always be very sensitive to the employees, it must be made as seamless as possible. Lewin's Change Theory consists of three objectives for human resource managers and executives to achieve, which includes making a radical change; minimizing the disruption of the structure's operations and ensuring that the change is adopted permanently (Morrison, 2014). This model provides guidance on how to motivate people to change: human resource managers and executives will implement new processes and re-assign tasks, but change will only be effective if the people involved will accept them and help putting it into practice. The first step of 'Unfreeze' emphasizes on identifying the bad habit that caused negative effects on the company's future development. The second step of 'Change' emphasizes that employees should identify their bad habits also need to change their old bad habits, and the change should be permanent. The final step is 'Freeze', which can be also called as refreeze. In this step, human resource managers and executives will provide reinforcements or rewards to motivate the employees who have changed (Morrison, 2014).

This application of Lewin's Change Theory is closely related to the concept of Total Quality Management (TQM) in a company, where human resource managers and executives contribute in business adaptability and adjustability. In recent times, Total Quality Management (TQM) is the trend that many companies are emphasized on it, where it aim at maximising the customer satisfaction and continuous improvement (Gilbert, 1992). To achieve this aim, the employees must change their bad habits and lapses. As a result, the degree of employee's resistance to change can be lower. Since employees will have a clear view about the full picture of the company's action plan, they will know that the changes of every employees are critically essential for the company to overcome the business adaptability and adjustability. Hence, human resource managers and executives act as a change mentor that can contribute to the team spirit and morale which in turn positively affects in building business adaptability and adjustability in the challenging economic environment.

\section{Contributions of Human Resource Managers and Executives in Building Business Adaptability and Adjustability}

\subsection{Transition the Human Resource Department to a Profitability Factor}

Human resources department can be the profitability factor that helps the business to produce 
profits. The followings can illustrate:

Human resource managers and executives can be involved in different departments' activities via their corporation. Traditionally, human resource managers and executives usually develop training programs with little thought given to overall corporate objectives. The poor training programmes developed employees' other competencies that may not directly impact their job performance. It made the training efforts became costly and unproductive. In view of this, Human resource managers and executives can communicate to different departments for the need of the employees. Then, human resource managers and executives can help establishing trainings that are related to business development, such as providing product trainings to marketing department in order to correspond with the new products launch of the business. In such involvement and interactions, they can help human resource managers and executives to ideally evaluate the training need of each employees by familiarizing the works of departments. Thus, human resource managers and executives can provide influential suggestions and effectively give the training program that meets the business' objective, and finally reduces the unnecessary cost and raises the profit of business.

Moreover, human resource managers and executives have a strong value to ensure the stability talents of employees. To intensify their duties, human resource managers and executives can hold all employees to have "critical numbers" achievements for business. (Moore and Furlong, 2016) The "critical numbers" of achievement can be based on the acceptance performance that within the employee's' control (e.g. work assignments and responsibilities) and evaluated them using the scorecard. With affirmed contribution of employees, the risk of business uncertainty is lower. Even in the adversity, human resource managers and executives can maintain the stability of employees' contribution and make use of them to bounce back the business.

Furthermore, human resource managers and executives are vital on business adaptability through using human capital to keep the profitability during challenges. It is the business ability to respond and adapt rapidly to threats posed to its workforce. Before the crisis, human resource managers and executives can address the people-related components, such as health and safety concerns, transportation concern, payroll concern of the employees when having crisis in business continuity planning. More importantly, keeping track of the employees also is critical for human resource managers and executives to prepare in advance. In case of the crisis, the precautions of human resource managers and executives can help lowering the human capital risk at maximum. Thus, the more human capital can be kept in work and maintain continuous operations. IBM had identified that the lower the risk of human capital in the crisis can have higher ability to maintain business operation. As a result, human resource managers and executives can maximize the knowledgeable employees (Intangible asset) to work and keep the revenue flowing.

\subsection{Human Resource Managers and Executives Make Profit to the Company}

By cooperating with other departments, human resource managers and executives act as profit contributors to improve company's profitability. 


\section{$\triangle$ Macrothink}

First, an American company formed a group of human resource experts, who developed the processes and training programs in different aspects like customer services and process improvement. They concentrated on issues which are critical for performance of their employees and external customers. By cooperating with different departments like the sales and operations, they initiated to form alliances, partnerships, and agreements. The work of human resource managers and executives translated the relationships into "Preferred Provider Status". The improved the relationships also increased the sales volume and decreased the costs. By using the same example, two years later, this group of human resource experts generated the sales of $\$ 4$ million and the profit margin excess 30\% (Moore \& Furlong, 2016). It shows that human resource department can relieve the financial burden of the company during the challenging economic environment.

Second, the human resource team in another company, which cooperating with the auditor, discovered that the Days Sales Outstanding ratio had increased from a preferred 30 days to 45 days during the past two years. Therefore, the company decided to replace the post of the chief credit officer, and the human resource department established criteria to find another qualified credit officer with the ability to reduce the ratio back to 30 days. The human resource department also recommended suitable candidate to hire. Within half a year, the company's ratio was reduced to 35 days (Moore \& Furlong, 2016). Therefore, capital liquidity can be enhanced which provide sufficient capital to business adaptability and adjustability.

As human resource managers and executives can help companies to recruit the right people into the right positions and develop the training programs, they help employees to improve their skills. The organization's profitability can be enhanced as the ability of employees are better utilized. With the increase of profitability, the company obtain sufficient capability to cope with the challenging economic environment.

\subsection{Engagement in People-Focused Approach to Business Continuity Planning for Crisis}

It is important for the companies to determine and address the human aspects of the business continuity plan through developing policies and communication, employee education and support and virtual infrastructure, to better react to the disaster.

Firstly, for policies and communication. Companies need to analyze and record policies and activities that will be the most important to employees before the crisis (IBM Global Services, 2009), to establish business adaptability and adjustability when the crisis occurs. Also, they need to outline the crisis communication strategies through different channels, so that to maintain the updated policies and status during the crisis.

Secondly, companies need to plan for employee education and support to respond crises. They can invest education programs to explain how to effectively prepare for and react to various types of crises, such as provides training, in order to build business adaptability and adjustability to respond crises. Moreover, companies can create a support network for employees, including counseling, medical and health services (IBM Global Services, 2009).

Thirdly, it is necessary for the company to review whether their virtual infrastructure working 
capabilities can satisfy employees' needs. By upgrading online equipment, communications technologies, remote support and intranet, company can obtain competitive advantage to prepare for the unexpected adverse economic situation and response to it as soon as possible.

Having a people-focused approach is useful for the development of business continuity plan. As a result, company can have the ability to overcome the challenging economic situations (IBM Global Services, 2009).

\section{Conclusion}

Through looking at the literature human resource managers and executives are having the important roles in building business adaptability and adjustability like acting as strategic partners, employee sponsors or advocates, change mentors and there were contributions including to transit the human resource department to a profitability factor; to make profit to the company and to engage in people-focused approach to business continuity planning for crisis.

\section{References}

eElderly. (2012). HSBC over-fired employees (in Chinese). Retrieved June 7, 2017 from https://www.e123.hk/ElderlyPro/details/154618

Gilbert, G. (1992). Quality Improvement in a Defense Organization. Public Productivity and Management Review, 16(1), 65-75.

Heathfield, S. M. (2016). The New Roles of the Human Resources Professional. Retrieved July 27, 2016, from https://www.thebalance.com/the-new-roles-of-the-humanresources-professional-1918352

Hong Kong Labour Department. (2015). Flexitime. Retrieved Sep 13, 2016 from http://www.labour.gov.hk/eng/public/wcp/Flexitime.pdf

IBM Global Services. (2009). In the spotlight: the human side of business continuity planning. IBM Corporation. Retrieved Nov 27, 2016, from https://www03.ibm.com/services/ca/en/cfo/documents/HCM_BusContinuity_white_paper.pdf

Moore, K., \& Furlong, R. (2016). Is Your Human Resources Department Profitable? What's Driving the Role of human resource as a Strategic Business Partner. Retrieved May 18, 2017 from https:/www.thebalance.com/the-human-resources-department-as-a-profitability-factor $-1918387$

Morrison, M. (2014). Rapidbi. Retrieved from Kurt Lewin change theory three step model unfreeze, change, freeze. Retrieved Oct 27, 2016 from https://rapidbi.com/kurt-lewin-three-step-change-theory/

OPM.GOV. (2017). A Handbook for Measuring Employee Performance. United States office of Personnel Management. Retrieved July 27, 2016, from https://www.opm.gov/policy-data-oversight/performance-management/measuring/employee_ performance_handbook.pdf 


\section{Macrothink}

Journal of Asian Development

ISSN 2377-9594 2017, Vol. 3, No. 2

Payton, C. (2015). Case study: Cross-train to gain. Retrieved July 27, 2016 from http://landscapemanagement.net/case-study-cross-train-to-gain/

Petti, R. (2012). Disaster Recovery and Business Continuity "Must Have" for Human resource managers and executives. Continuity Insights 2013 Management Conference. Retrieved May 18, 2017 from http://documentslide.com/documents/disaster-recoveryand-business-continuity-must-haves-for-human resource-professionals-56cf05614b3c0.html

Rouse, M. (2014). Business adaptability and adjustability. Retrieved Sep 13, 2016 from http://searchcio.techtarget.com/definition/business-adaptability and adjustability?vgnextfmt=print

Ulrich, D. (1997). Human resource champions: the next agenda for adding value and delivering results. Boston, MA: Harvard Business School.

\section{Copyright Disclaimer}

Copyright for this article is retained by the author(s), with first publication rights granted to the journal.

This is an open-access article distributed under the terms and conditions of the Creative Commons Attribution license (http://creativecommons.org/licenses/by/4.0/). 